\title{
DEL SIMIO DE DIOS AL EXOTISMO DEL PARAÍSO. CONSIDERACIONES SOBRE LA PRESENCIA DEL MONO EN LA ORNAMENTACIÓN ARQUITECTÓNICA DE LAS IGLESIAS COLONIALES SURPERUANAS
}

\author{
FROM GOD'S APE TO THE EXOTIC PARADISE. CONSIDERATIONS ABOUT \\ THE MONKEY'S PRESENCE IN THE ARCHITECTURAL ORNAMENTATION \\ OF SOUTHPERUVIANS COLONIAL CHURCHES
}

\author{
Carla Maranguello*
}

\begin{abstract}
Desde la Antigüedad, en la tradición cristiana, el mono ha sido asociado con características esencialmente negativas, connotación que se sostuvo durante el cristianismo, donde su figura llegó a utilizarse para representar al mismo Satán y otras actitudes deplorables del hombre. Por el contrario, en los Andes prehispánicos el animal aparece asociado al exotismo y a la abundancia vegetal de la Amazonía, así como a diversos mitos relativos a los astros, pero siempre atribuido de connotaciones positivas. En la ornamentación arquitectónica de los templos de la provincia de Chucuito en el sur de Perú, desarrollados durante los siglos XVII y XVIII, aparecen los monos ocasionalmente y su ubicación se repite en portadas que dan acceso a espacios de culto, junto con otros elementos naturales de raigambre prehispánica, así como con símbolos del universo cristiano. Los estudios al respecto no han elaborado interpretaciones definitivas de la aparición de estas figuras en el contexto colonial, por lo que parece pertinente repasar la significación del animal en la tradición medieval y en el mundo prehispánico, para luego examinar las imágenes considerando el contexto de ejecución de los programas ornamentales y su función en el marco del adoctrinamiento.
\end{abstract}

Palabras claves: Monos, religiosidad andina, ornamentación arquitectónica, Chucuito colonial.

Since ancient in Christian tradition, the monkey has been associated with, essentially, negative characteristics, connotation held during christianity, even was used to represent Satan and other deplorable attitudes of man. In oposition, in pre-Hispanic Andes the animal appears associated with the exoticism and forest abundance in the Amazon, as well as various myths about the stars, but always attributed positive connotations. In the architectural ornamentation of colonial temples in Chucuito's province in the southern Peru, developed during the $17^{\text {th }}$ and $18^{\text {th }}$ century, monkeys appear occasionally, and its location is repeated in access doorways to places of worship, with other natural elements of pre-Hispanic tradition and with the Christian's symbols. Studies in this field haven't produced definitive interpretations of the appearance of these figures in the colonial context, so it is appropriate to consider the significance of the animal in medieval tradition and the pre-Hispanic world, and then to examine the images, to made a consideration of the context of implementation of ornamental programs and their role in the doctrinal context.

Key words: Monkeys, andean religiosity, ornamental iconography, colonial Chucuito.

\section{Introducción}

Desde los inicios del cristianismo fue común adoptar diversos motivos paganos de las zonas por las que se divulgaba la doctrina, por dentro y por fuera de Europa latina, para convertirlos a la representación de Cristo. Por otra parte, los símbolos con que contaba la misma tradición del Imperio Romano y que arrastraba formas del Antiguo Cercano Oriente, las culturas del Mar Egeo y la Antigua Grecia, fueron tomados y resignificados por el cristianismo, ampliando o modificando el sentido primero. El hecho de centrar la conversión de estos motivos básicamente en la idea o contenido, con la posibilidad de conservar gran parte de la forma original, permitió que se fijaran con rapidez y efectividad la mayor parte de ellos. En este sentido, hubo diversas fuentes que actuaron como guía, modelo o mero referente en las imágenes, principalmente los libros de los primeros naturalistas de la antigüedad grecorromana, cuyas compilaciones fueron utilizadas luego por los bestiarios medievales, siendo uno de los más destacados El fisiólogo. En dichas fuentes, el cristianismo encontró una forma de plantear lecciones de carácter didáctico y moral, presentando alegorías entre Cristo y el buen

* Universidad de Buenos Aires, Facultad de Filosofía y Letras, Departamento de Artes. Instituto de Teoría e Historia del Arte "Julio E. Payró". Buenos Aires, Argentina. Correo electrónico: carlamaranguello@ hotmail.com 
cristiano y las características y comportamientos de los distintos animales y del resto de los elementos naturales (Charboneaux Lassay 1996).

Así como la mayor parte de los símbolos consagrados a Cristo representaban algunas veces también al fiel cristiano, lo mismo sucedió con la figura de Satán. Muchos animales fueron asociados al diablo por sus características, y la figura del mono fue una de las privilegiadas por sus comportamientos y rasgos físicos, siendo conocido el anticristo como el simio de Dios (Walker Vadillo 2013). En América, las imágenes del repertorio cristiano sufrieron un proceso de transformación, siendo dotadas de características nuevas de acuerdo con asociaciones con el pasado prehispánico y las condiciones geográficas del nuevo mundo, especialmente los elementos vinculados a la flora y la fauna, ya que tenían importancia para la vida medicinal, económica, religiosa y política.

En la ornamentación arquitectónica de las iglesias coloniales surperuanas de fines del siglo XVII y todo el siglo XVIII, vemos aparecer la figura del mono ocasionalmente, en un nivel bajo de representación en relación con otros motivos, ubicada siempre en accesos a diferentes espacios de culto y rodeada de vegetales de raigambre prehispánica, pájaros y símbolos cristianos, lo que nos lleva a interrogarnos acerca de la intención de ubicar la figura en estos sitios tan puntuales. Examinaremos algunos antecedentes destacados de la representación del animal en el cristianismo y en América, para considerar, mediante dos ejemplos de la doctrina de Juli, la importancia del contexto de aparición y uso, en el marco del adoctrinamiento que tuvo lugar en la zona.

\section{Los monos en la iconografía cristiana}

En el arte cristiano, desde la época medieval, los monos aparecen representados con connotaciones esencialmente negativas, más allá de las variantes que puedan presentar. Como una especie de descendencia degenerada del ser humano por sus características físicas, lo que tendría su réplica en conductas morales dudosas, la figura del mono fue sustentándose desde la antigüedad en el dicho del poeta latino Ennio, referido en Cicerón y Opiano como un ser repugnante, de mal aspecto, desagradable de contemplar pero de mente astuta: simia quam similis turpissima bestia nobis $^{1}$ (García Arranz 2013: 215). Luego en la Edad
Media su reputación no mejoró. En afinidad con los escritos clásicos, se aplicó el término simia a todos los enemigos de Cristo, desde los paganos y apóstatas hasta los heréticos e infieles, pero siempre asociado al pecado o a la idolatría. Las fuentes literarias y las imágenes en las que aparecen los monos en esta época son muy variadas, pero en todas se mantiene el aspecto despectivo. Destacan los bestiarios, las fábulas y los exempla, aunque también numerosas fuentes clásicas fueron utilizadas. En el arte aparecen en los portales de las iglesias románicas y en algunas miniaturas, basados por lo general en fuentes literarias.

A partir de las descripciones de los primeros naturalistas, en donde los monos aparecen como seres desagradables pero similares al hombre y que intentan emular sus conductas, comenzó a pensarse al animal como una suerte de caricatura desvirtuada y grotesca del ser humano, siendo perfecto para representar al diablo, quien además de ir en contra de los valores cristianos, trataba de imitar a Dios, por eso fue llamado el simio de Dios. Según Mónica Walker Vadillo, esta situación pudo tener su origen en Egipto, donde el pueblo hebreo durante el Éxodo habría visto la adoración al babuino, que era considerado un dios del inframundo-Babi- que se comía a las almas de los injustos y se las llevaba al fuego para destruirlas-. En consecuencia, se asoció a este animal con el inframundo y el fuego, haciendo más fácil su identificación con el demonio en el cristianismo. El Salterio de Stuttgart (c.800), que sigue al Salmo 77, presenta al simio con un sátiro remitiendo a fuerzas malévolas de Egipto, bloqueando el camino a los israelitas y con la misma connotación aparece en la escena de la hija del faraón y Moisés de la pila bautismal del maestro Roberto para la iglesia de San Frediano en Lucca (c. 1100) (Walker Vadillo 2013).

Entre los libros más utilizados como referente destaca El fisiólogo, escrito en Alejandría entre los siglos II y V d. C., habiendo sido el libro más difundido después de la Biblia y que sobrevivió hasta el Renacimiento. Se trata de una compilación seudocientífica que redondea una visión del mundo zoológico medieval (real y fantástico), recogiendo descripciones e historias de animales, que añadió a los libros de los naturalistas imágenes tomadas desde la antigüedad grecorromana mediante alegorizaciones doctrinales y moralizantes cristianas, por lo que se considera fundamental para el desarrollo de los bestiarios medievales. Allí se menciona al 
simio junto con el asno salvaje -el onagro-y al igual que él, asumiría el papel de diablo, caracterizándose por la falta de cola (Guglielmi 1971). Algunos bestiarios añaden variantes, pero en su mayoría con connotaciones negativas, asociando al animal con el pecado, la lujuria y la vanidad ${ }^{2}$. Dentro de las fábulas, los autores refieren a Esopo (siglo VI a. C.), en donde destaca la asociación del simio con el diablo y con el pecado o acciones negativas del humano, ya que aparece como un animal feo, mentiroso y con intenciones de imitar al hombre. Una de las fábulas más mencionadas es la que alude a la maternidad, en donde una simia que tiene dos crías protege extremadamente a una mientras que deja de lado a la otra. Como consecuencia, la cría más amada termina muriendo sofocada por el exceso de cariño de su madre, mientras que la cría despreciada sobrevive. Esta fábula aparece representada en bestiarios donde la hembra simio con gemelos lleva a la cría en brazos y a la despreciada en el cuello, mientras es perseguida por un cazador (Walker Vadillo 2013). Figura 1. Esta historia del mono con características deplorables desde el punto de vista humano reemplazó a la teoría del simio demonio y cobró mayor dimensión por medio de los exempla, que las órdenes mendicantes desde la baja Edad Media (siglos XII-XIV) comenzaron a utilizar como enseñanzas moralizantes acompañando los sermones. En el caso de los monos, la madre simia era la pecadora, con la cría protegida refería a los placeres del cuerpo, y con la despreciada representaba el peso de los pecados, ya que era esta cría la que hacía que la madre perezca ante los cazadores, por lo que también su figura se convirtió en símbolo del vicio generalizado y los bajos instintos (Walker Vadillo 2013; García Arranz 2013).

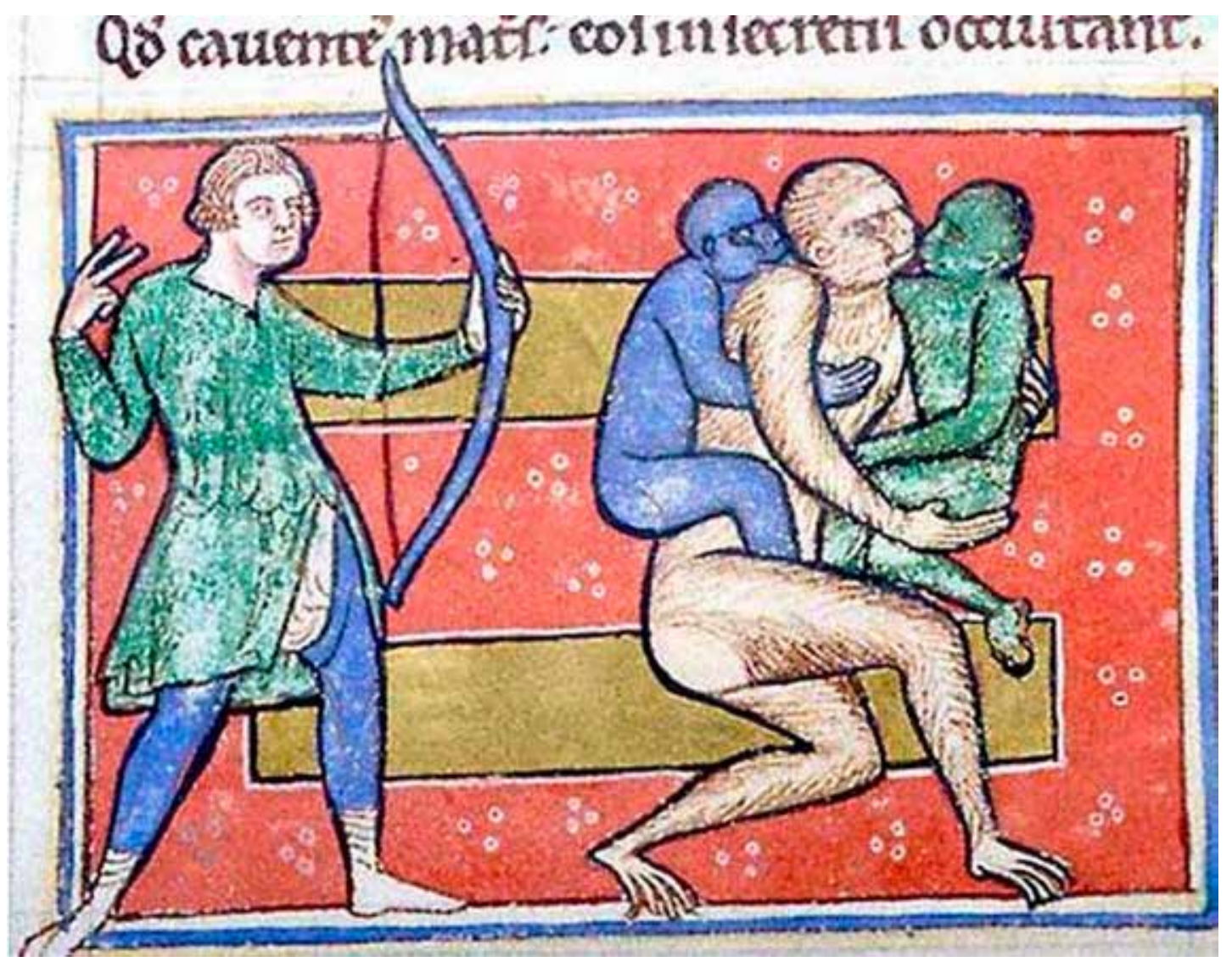

Figura 1. Bestiario Workshop (Inglaterra). c. 1185. Nueva York. The Pierpont Morgan Library, Ms. M. 18, fol. 19v. Fuente: Walker Vadillo 2013: 76. 
Hacia el Románico se retomó el interés en el mono en cuanto a las actitudes detestables del hombre como la pereza, el vicio y el abandono a los pecados de la carne, por lo que es común ver al animal encadenado e impulsado por demonios, atacado o mordido por serpientes, entre otras variantes. Esta iconografía aparece en capiteles románicos de iglesias españolas, siendo el caso más destacado el de la puerta de las platerías de Santiago de Compostela en España (c. 1101-1111), donde se presenta un mono alado haciendo referencia al diablo en las tentaciones de Cristo, agachado y encadenado por una soga al cuello (García Arranz 2013). Figura 2. Tanto en los bestiarios como en los capiteles de las iglesias la representación del animal se acerca al modelo real, aunque las limitaciones del soporte y de la época le otorguen un sesgo un tanto esquemático.

Hacia el Renacimiento, la vinculación del mono con el vicio y la falta de moral se utilizó en referencia explícita al pecado original, cargando con todas las connotaciones negativas desde la Antigüedad, y siendo figurado por lo general como el mono frugívoro, el que que sostiene o come una manzana. Arranz menciona el caso de la miniatura que representa a Adán nombrando a los animales, del frontispicio del Bestiario inglés de la Biblioteca Nacional de San Petesburgo, (fines del siglo XII), en el que frente al primer hombre se sienta un mono con una manzana en la mano, lo que para el autor ya anticiparía la caída del género humano. Luego, la tendencia a identificar al mono con el apetito carnal aumentó, apareciendo en escenas junto con Adán y Eva hacia el siglo XVI, o yendo aún más lejos identificándolo con la propia Eva, tal como se ve en el grabado de Erhard Altdorfer, "Adán y Eva en el paraíso" (c. 1533), en donde se reemplaza a la serpiente por dos monos agarrados de las ramas que reproducen la escena de la tentación, situación que Eva mira y señala, proyectando una futura imitación (García Arranz 2013). En contraposición, aparece el mono encadenado acompañando a la figura de María, ya que la Virgen era la reparadora de la conducta de Eva, como se ve en el grabado de Alberto Durero "La virgen del mono" (c. 1498). Figura 3, apareciendo también en escenas de Epifanías ${ }^{3}$. En estos casos y acorde a las búsquedas de realismo de la época, la representación del animal es mimética.

En cuanto a las significaciones, si bien posteriormente se añadirán intereses por la representación de ejemplares reales en las pinturas, la connotación negativa atribuida al animal desde el cristianismo, se sostuvo con los siglos.

\section{Los monos en América colonial: antecedentes prehispánicos e interpretaciones}

La provincia de Chucuito, ubicada en el Dpto. de Puno, en Perú, presenta un conjunto de iglesias reduccionales que fueron organizadas por el virrey Francisco de Toledo desde 1573, quien expulsó un año antes a los dominicos que se habían encargado de la primera evangelización en la zona y los reemplazó por integrantes del clero secular. Los jesuitas, que tomaron la doctrina de Juli en 1576 y estuvieron allí hasta su expulsión en 1767, acompañaron el proceso de desarrollo de los programas iconográficos de la ornamentación arquitectónica eclesiástica, que desde fines del siglo XVII y durante el siglo XVIII estuvo a cargo de grupos nativos. Dicha ornamentación se extiende en las portadas de acceso a diferentes espacios de culto y jugó un rol sustancial para la orientación del circuito religioso y como elemento de transición entre los diferentes espacios. Destacan en las portadas gran cantidad de aves pertenecientes al entorno, variedades de flores y plantas de empleo ritual y alimenticio, valvas marinas, animales relevantes en la iconografía andina como felinos y, en menor medida, los monos. Esta iconografía se superpone a diferentes elementos de la simbología cristiana, como monogramas de María y de Cristo, símbolos de las órdenes religiosas, elementos de la Pasión y diferentes tipos de ángeles. La presentación de elementos naturales que reemplazan muchos motivos usados para ornamentar las portadas europeas, por plantas y animales del altiplano y de otros pisos ecológicos, resulta significativa, ya que para el hombre andino la naturaleza tenía en sí misma contenidos religiosos (Sillar 2009), aspecto que se revela en la mayor parte de la iconografía de las producciones artísticas que van desde antes de la cultura Chavín hasta la conformación del Tawantinsuyu ${ }^{4}$. El origen de este estilo se ubica en la fachada de la Compañía de Arequipa (1698-99), el que se extendió rápidamente hacia el Sur, teniendo impacto especialmente en la provincia de Chucuito mediante la influencia de la iglesia de Santa Cruz de Juli, según documentación citada por Alexander Gauvin Bailey, apareciendo en las iglesias de San Pedro de Zepita (c. 1735), Santiago de Pomata (c. 1754-1794), San Carlos de Puno (c. 1787) para 


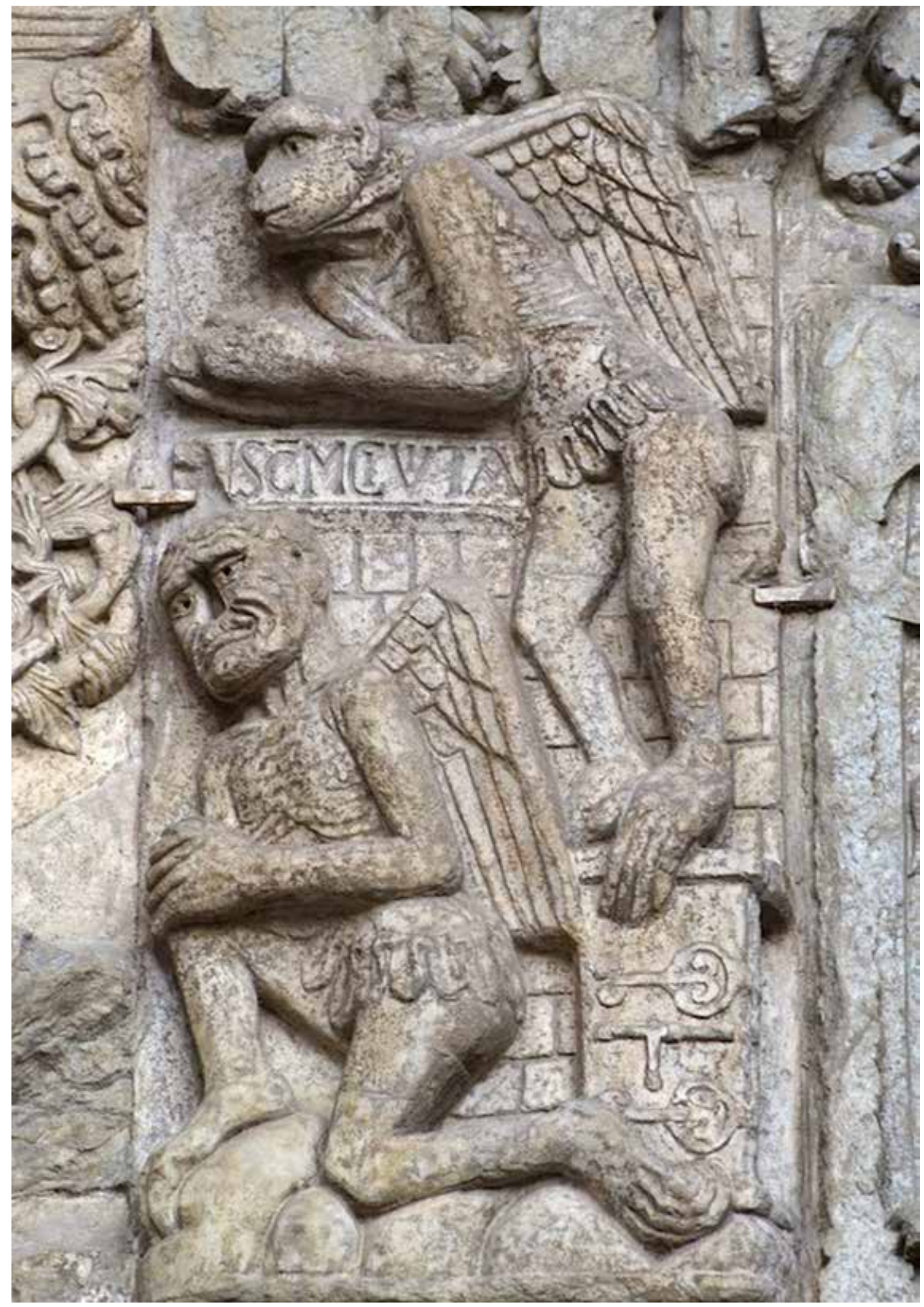

Figura 2. Simio alado en las Tentaciones de Cristo. Tímpano septentrional de la Portada de Platerías de la Catedral de Santiago de Compostela (España). c. 1101-1111. Fuente : Walker Vadillo 2013: 75. 


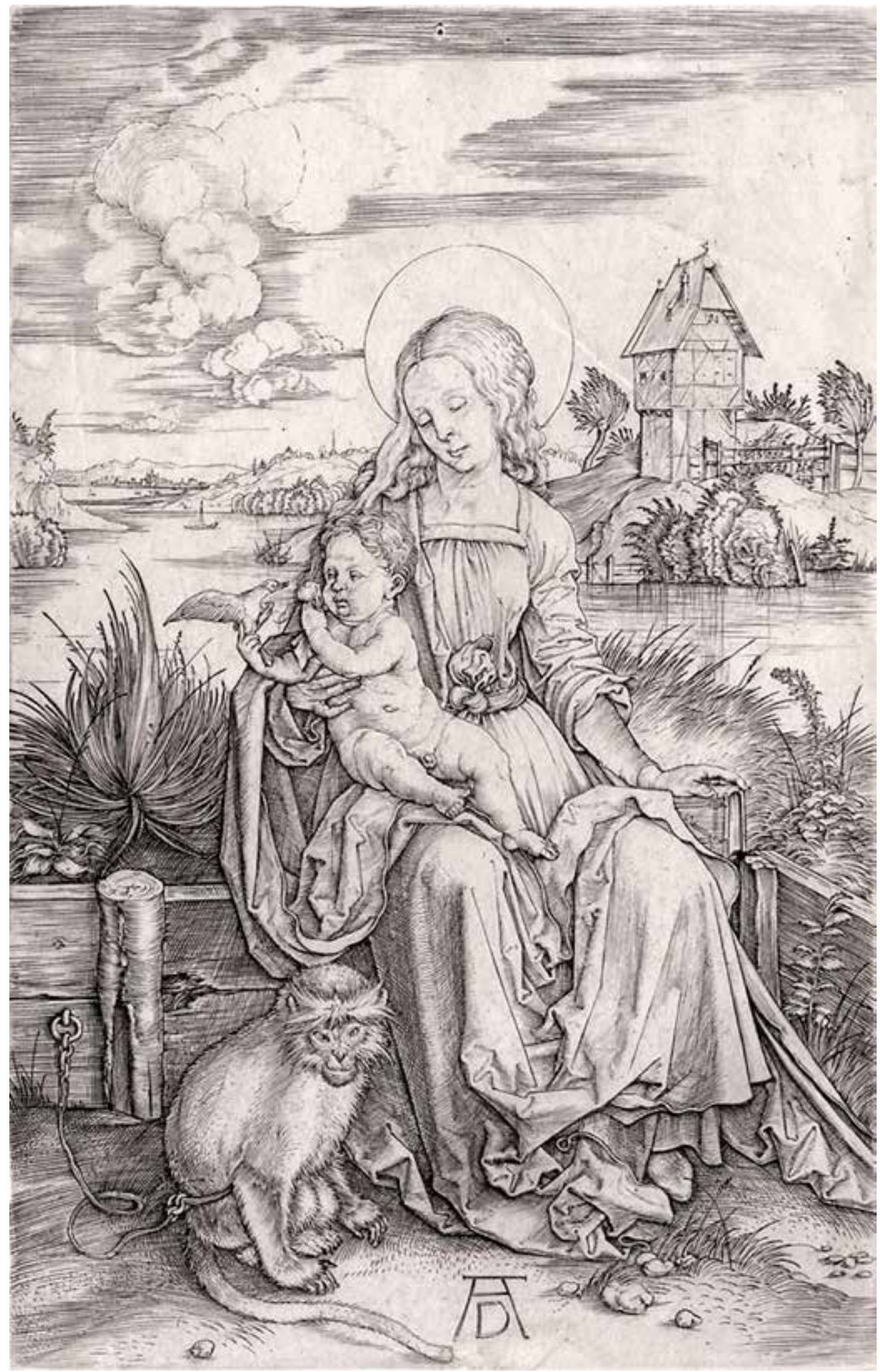

Figura 3. Alberto Durero, Virgen del mono, grabado calcográfico. Londres, Museo Británico. c. 1498. 19’1 x 12’3 cm. Fuente: García Arranz 2013: 217. 
expandirse finalmente a varias ciudades del Alto Perú, como La Paz y Potosí (Bailey 2010).

El caso más notorio es la portada de acceso al bautisterio de la Iglesia de Santa Cruz en Juli (c. 1712 y 1753) y su réplica, una portada enfrentada que presenta las mismas características, pero cuyo uso preciso se desconoce. Figura 4. Esta iglesia respondía al modelo de nave única en cruz latina y fachada retablo. En su interior se ubica la portada del Bautisterio, mediante una composición simétrica, organizada a partir de un arco de medio punto sobre pilastras, flanqueado con exentas columnas pareadas. En sus bases se hallan cuatro monos de cada lado, que se alimentan de cacaos, similares a los tipos de Solanum muricatum, una cucurbitaceae que todos los cronistas mencionan y que se cultiva en las tierras calientes, apareciendo en cerámicas precolombinas Chimú (costa norte de Perú- c. 12001400 d.C.) donde se muestran los frutos ya pareados o en conjuntos de tres o cuatro ejemplares acoplados. Estos motivos se combinan con zarzaparrillas, que son frutos similares a las uvas que crecen en las tierras yuncas (Maranguello 2011). El tratamiento formal de los monos es un tanto esquematizado, igual que el resto de los elementos naturales, lo que seguramente se deba a las limitaciones del soporte, ya que denota la intención de referir al modelo real. Figura 5. Sobre estos elementos y en la misma columna, flanqueando el arco de acceso, destaca la presencia de datura o chamico del género Brugmansia, que ya aparece en el arte lítico desde culturas del Horizonte Temprano como Chavín de Huantar (sierra de Ancash- c. 900-200 a.C.), particularmente en el Obelisco Tello, en íntimo vínculo con el sistema religioso y que debió corresponder a la capacidad de dicho vegetal de producir algún efecto alucinógeno en sus propiedades (Mulvany de Peñaloza 1984). Rematan el acceso a la portada en la dovela del arco, tres valvas dispuestas de manera simétrica junto con representaciones de panochas de maíz, y constituyen el eje central de la composición, alineados con el símbolo de la orden de la Compañía de Jesús. Si bien las valvas aparecen en la iconografía cristiana como atributo de Santiago el Mayor (Charboneaux Lassay 1996), en el mundo andino se consideraban especialmente por la importancia que tenían como ofrendas acuáticas, apareciendo ya desde Chavín las conchas Spondylus y los Strombus vinculados a rituales de fertilidad, utilizados como ofrendas para atraer a las fuerzas naturales a una relación recíproca con la sociedad
(Burger 1983; Rick 2012). Por su parte, el maíz era la principal ofrenda en sacrificios y al igual que las hierbas de uso alucinógeno, sus sustancias embriagantes se correspondían con la asignación de valor de médium con estados alterados de conciencia. Estos elementos se relacionan con la importancia de la regeneración de la vida, inscribiéndose en el principio básico de la ideología de fertilidad (Maranguello 2011).

Por otra parte, vale mencionar el caso del interior de la iglesia de San Juan de Juli que corresponde a la misma etapa de ejecución (concluida antes del año 1767$)^{5}$ y que presenta decoración labrada en madera en los abocinamientos de las ventanas de la nave central. En el registro inferior, aparecen monos agachados, en un marco de elementos florales y vegetales al modo de grutescos, con remates de mascarones y aves. Asimismo, en las esquinas opuestas a la ubicación del mono aparece un hombre desnudo y de pie, probablemente un nativo, sosteniendo flores campaniformes al estilo datura. El tratamiento formal de las figuras es similar al del bautisterio. Figuras 6 y 7 .

En la larga historia de la iconografía andina prehispánica, los monos aparecen representados en menor grado que otros animales más destacados, como el felino, el halcón y la serpiente. Para las áridas tierras del Collao y la zona de la costa y la sierra, los monos serían vistos como animales exóticos de la selva, junto con el resto de los elementos naturales que pertenecen a otros pisos ecológicos, presentando un valor positivo, ya que alude a la capacidad de conexión y obtención de recursos, y más allá de las variantes que manifiestan, aparecen vinculados junto con otros elementos naturales, a la idea de fertilidad. Estas hipótesis se basaron principalmente en la iconografía de las producciones artísticas, ya que a diferencia del cristianismo, no aparecen fuentes escritas vinculadas.

Gisbert y Mesa indagaron acerca de la figura del mono en las iglesias del virreinato del Perú, resaltando los casos aislados en los que aparece el animal. Entre estos casos puede mencionarse la iglesia de Tiahuanaco (c. 1612), donde los monos aparecen en número de cuatro en los pedestales de las columnas de la fachada de acceso, y que según los autores sería la representación más temprana del tema. Cronológicamente sigue la iglesia de Laja (c. 1697 y 1724), en donde aparecen los monos sentados, sosteniendo en las manos una fruta, y de los que habrían derivado 


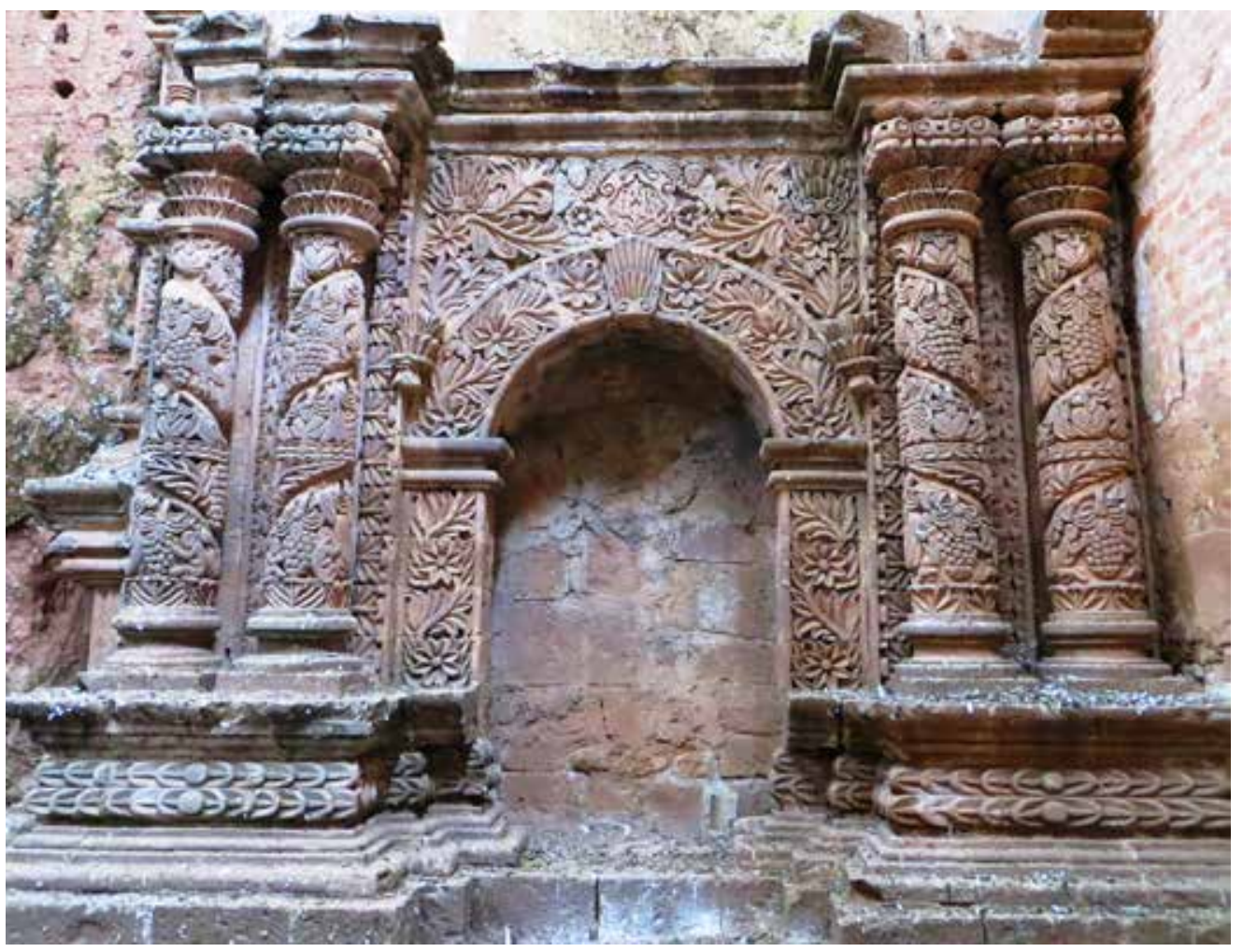

Figura 4. Bautisterio de la Iglesia de Santa Cruz de Juli. Puno, Perú. (c. 1722). Fuente: Carla Maranguello. Trabajo de campo/ fieldwork-Ubacyt 2013.

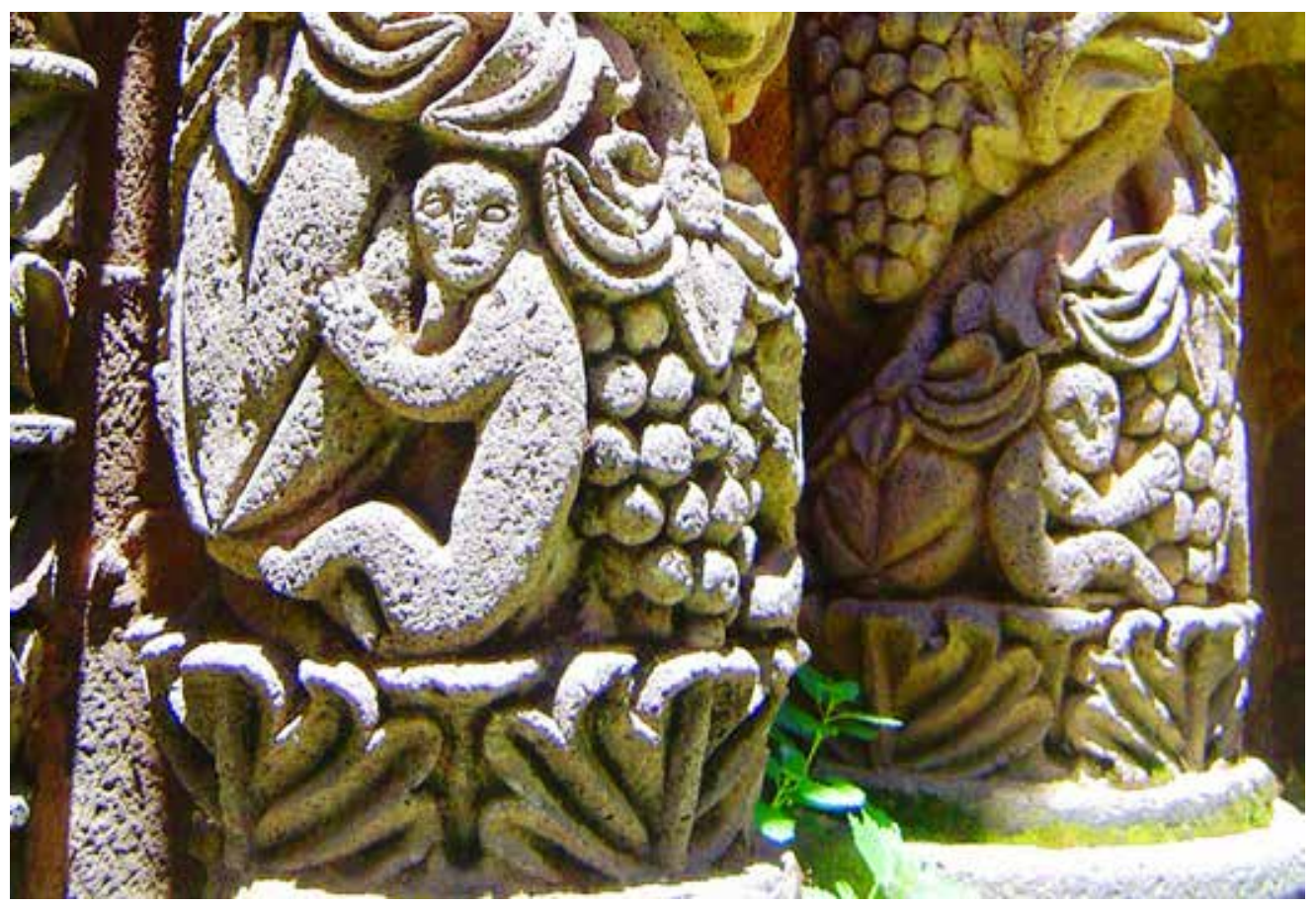

Figura 5. Detalle de los monos en el bautisterio de la Iglesia de Santa Cruz de Juli. Puno, Perú. (c. 1722). Fuente /Source: Carla Maranguello . Trabajo de campo/fieldwork-Ubacyt 2013. 


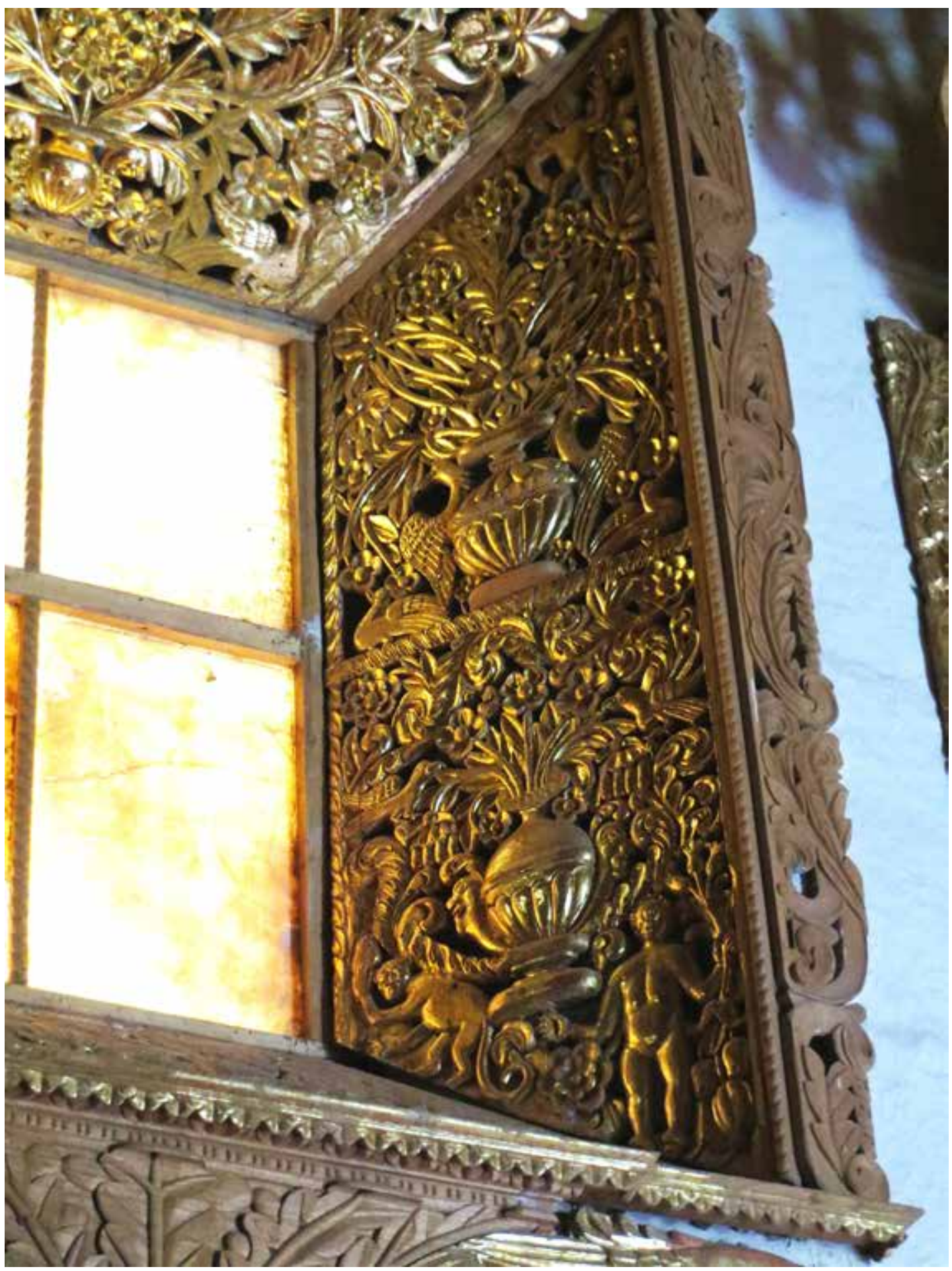

Figura 6. Ventana en Iglesia de San Juan de Juli Puno, Perú. (c. 1767). Fuente: Carla Maranguello .Trabajo de campo/fieldwork-Ubacyt 2013. 


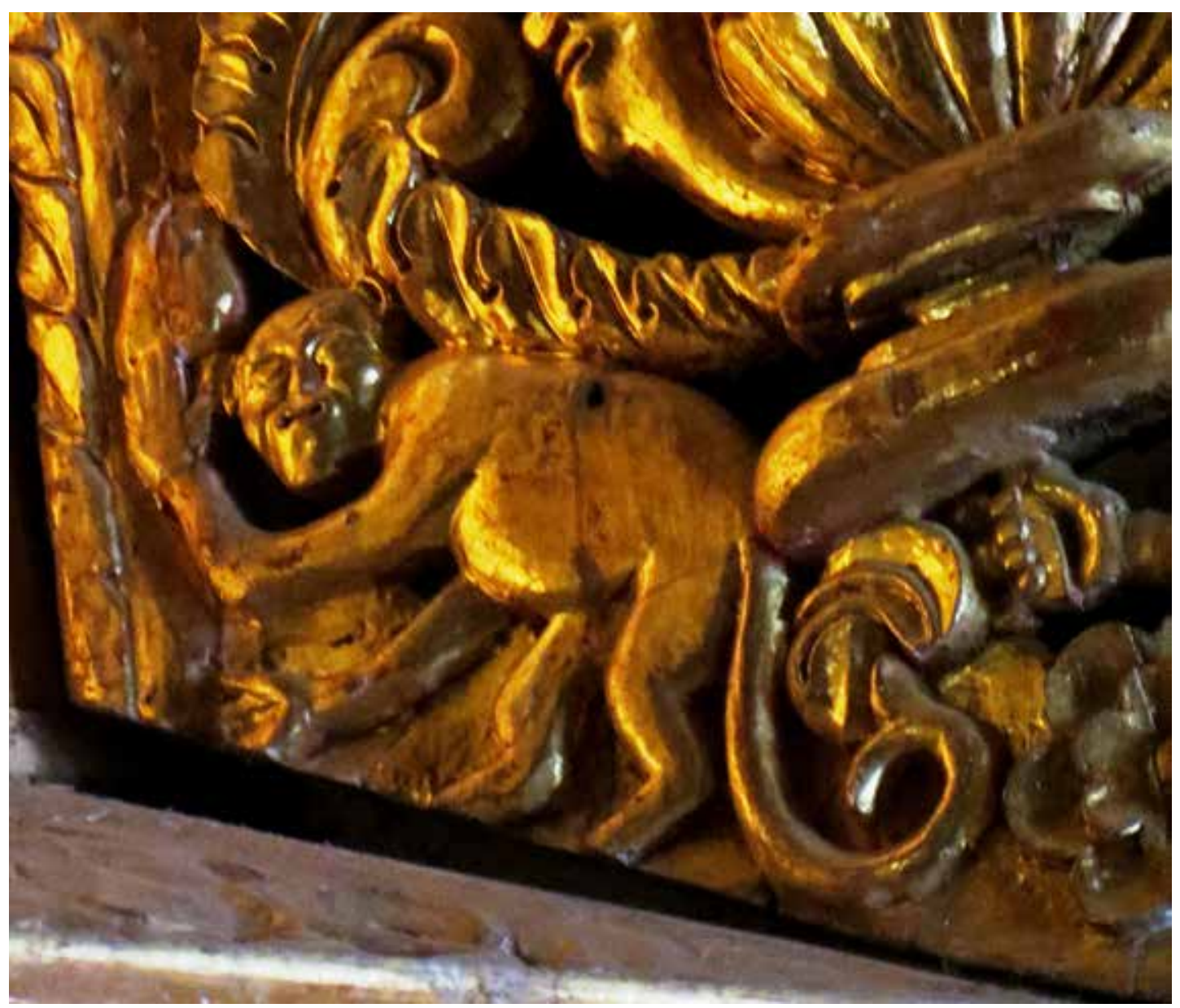

Figura 7. Detalle del mono en la Iglesia de San Juan de Juli Puno, Perú. (c. 1767). Fuente: Carla Maranguello. Trabajo de campo/ fieldwork-Ubacyt 2013.

los del bautisterio de la iglesia de Santa Cruz de Juli (c. 1712) y finalmente en la iglesia de Puno (c. 1757) aparecen de la misma forma (Gisbert 1981; Gisbert y Mesa 1985) ${ }^{6}$. En todos los casos, las figuras son esquematizadas, pero la referencia al modelo real es clara. Gisbert y Mesa recuperan un relato del cronista José de Arriaga [1621] quien, en el contexto de extirpación, recordaba la visión de los padres Ávila y Cuevas en Huarochirí, donde aparecen dos monos de madera labrados en las ventanas de una iglesia que no especifican, y que habrían sido quemados por ser considerados como deidad sustentante de edificios: "en las ventanas de una iglesia echamos de ver muy acaso, que estaban dos micos de madera, y sospechando lo que era, se averiguó que los reverenciaban porque sustentasen el edificio, y tenían sobre ello una larga fábula" (Gisbert y Mesa 1985: 262). Asimismo, refuerzan esta teoría por aparecer la temática de un mono abrazando columnas de un edificio en un vaso de la cultura Chimú, razón por la que destacan su presencia, por lo general, en las bases de las columnas de las iglesias (Gisbert y Mesa 1985). No obstante, el relato del cronista no tiene mayor sustento ni se encontró alguna otra fuente al respecto que confirme la condición de deidad sustentante de edificios de los monos. Posteriormente añade Teresa Gisbert nuevas interpretaciones en donde los elementos de la zona selvática en general, sin hacer mención específica de algún tipo de mono, se relacionarían con la significación del paraíso en el mundo cristiano y su adecuación al mundo andino según la interpretación del paraíso que estableció el cronista León Pinelo [1656]. El mono junto con otro tipo de fauna y flora, aludiría a la abundancia del Antisuyu, en la 
Amazonía (Gisbert 1999), sosteniendo entonces el significado de exotismo que presentó en las culturas prehispánicas de la zona.

Hiroshi Okada vinculó a estos animales, junto con las sirenas y los grandes loros de plumas coloridas, a estereotipos de lo exótico relativos al continente americano desde la visión europea y que los mismos nativos al insertarse en el sistema colonial asumieron en relación con los habitantes de su propia tierra para confrontar la imagen del europeo, por lo que se trataría de un "exotismo invertido" (Okada 2006:75). Estos animales aparecieron ya desde las representaciones cartográficas que hacían referencia a diferentes zonas de América, lo que luego se trasladó a los libros de viaje, y en todos los casos estos estereotipos se vincularían con el poder, ya que muestran la expansión imperial por el continente, evidenciando sus maravillas geográficas y faunísticas donde los monos ocupan un lugar destacado. Un ejemplo lo constituye un mapa alegórico de Perú hecho por Guamán Poma de Ayala [1615-16], en donde se evoca al Tahuantinsuyo en la ordenación cuadripartita, apareciendo Cuzco y la figura de Inca debajo del escudo del imperio español y de la orden papal, flanqueado todo el mapa por monos, loros, e incluso sirenas y unicornios, refiriéndose a América como la tierra de lo exótico y maravilloso (Okada 2006). No obstante esto no habría sido posible sin la aceptación de aquellos nativos que encontraron una forma de representarse en el nuevo contexto, ahora convertidos al cristianismo. Por otro lado, para Alexander Gauvin Bailey, los monos de la Iglesia de la Santa Cruz, al igual que los que él identifica como titi por su pequeño tamaño con melena de león y grandes garras en la fachada lateral de la iglesia de San Juan en Juli ${ }^{7}$, se explicarían por el paso en Juli a intervalos regulares de los jesuitas y doctrineros de las misiones de la Amazonía, reduciendo su aparición nuevamente a la curiosidad por un animal de otra zona ecológica (Bailey 2010). El autor, al igual que sus predecesores, no hace referencia a la condición negativa que arrastraba el mono desde la Antigüedad y a su consolidación en el cristianismo.

Algo similar sucede con las crónicas de la época. Quienes describen la fauna nativa, si hacen referencia al mono es más bien como un animal curioso por la diversidad de tamaños y actitudes simpáticas, junto con otros animales traídos de la zona selvática “(...) En los Andes se crían monos y micos muchos y muy graciosos, y papagayos en cuantidad (...)" (Acosta 1954 [1590]: 80). Por otro lado, destacan su similitud con los hombres por su inteligencia: "los indios tienen para sí que son hombres montaraces, y que no hablan por no servir ni pagar tributo" (León Pinelo 1943 [1656] II: 65) e incluso respecto de las crías, subrayan su comportamiento por el extremo cuidado que les profieren, sin hacer referencia a las fábulas que lo asocian al vicio y al pecado: “(...) Crían los micos con grande amor a sus hijos, trayéndolos en brazos a tiempos muy apretadamente (...)" (Cobo 1892 [1657] II:312). La mención de Bernabé Cobo resulta interesante, porque también menciona al animal con el alimento, proyectando una imagen similar a la que aparece en el bautisterio: “(...) nace el cacao en tierras yuncas (...) los monos que se crían en los árboles grandes hacen abrigo y comen del cuanto pueden [...]" (Cobo 1892 [1657] II: 6263). Guamán Poma de Ayala (1936 [1613]) hace referencia a los monos en sus ilustraciones, donde aparecen asociados a las mujeres de los incas, ya que junto con el papagayo constituían elementos valiosos de las tierras bajas. Excepcionalmente Pedro Cieza de León refiere en otra sección a una fábula en donde una suerte de monas salvajes residentes en el interior de una montaña en los Andes: "[...] andan por los árboles, con las cuales por tentación del demonio (...) estos usan con ellas como mujeres. Y afirman que algunas parían monstruos que tenían las cabezas y miembros deshonestos como hombres, y las manos y pies como mona (...)" (Cieza de León 2005 [1550]: 246).

Sin embargo, a estos animales exóticos ya podemos verlos instalados en el imaginario de los pobladores de las áridas pampas de San José y Palpa en los geoglifos de Nazca y la textilería, así como en la cerámica Chavín y Moche, entre otros. Esto no ha de sorprender, ya que desde las épocas más tempranas como Chavín puede verse la representación de lagartos, jaguares y águilas, e incluso en menor medida monos, como animales pertenecientes a las tierras calientes, alejados de la zona serrana y que responderían, según Richard Burger (1993), a la necesidad de superar los límites de los hábitos cotidianos. Figura 8. En la misma línea Reinhard, al establecer interpretaciones respecto de los geoglifos de Nazca (Valle de Ayacucho, c. 300-500 d.C.), menciona al mono como protector o símbolo acuático debido a pertenecer este animal a zonas en donde abunda el recurso hídrico. Si los geoglifos se utilizaban como caminos sagrados para alcanzar lugares vinculados con el agua, principalmente las 


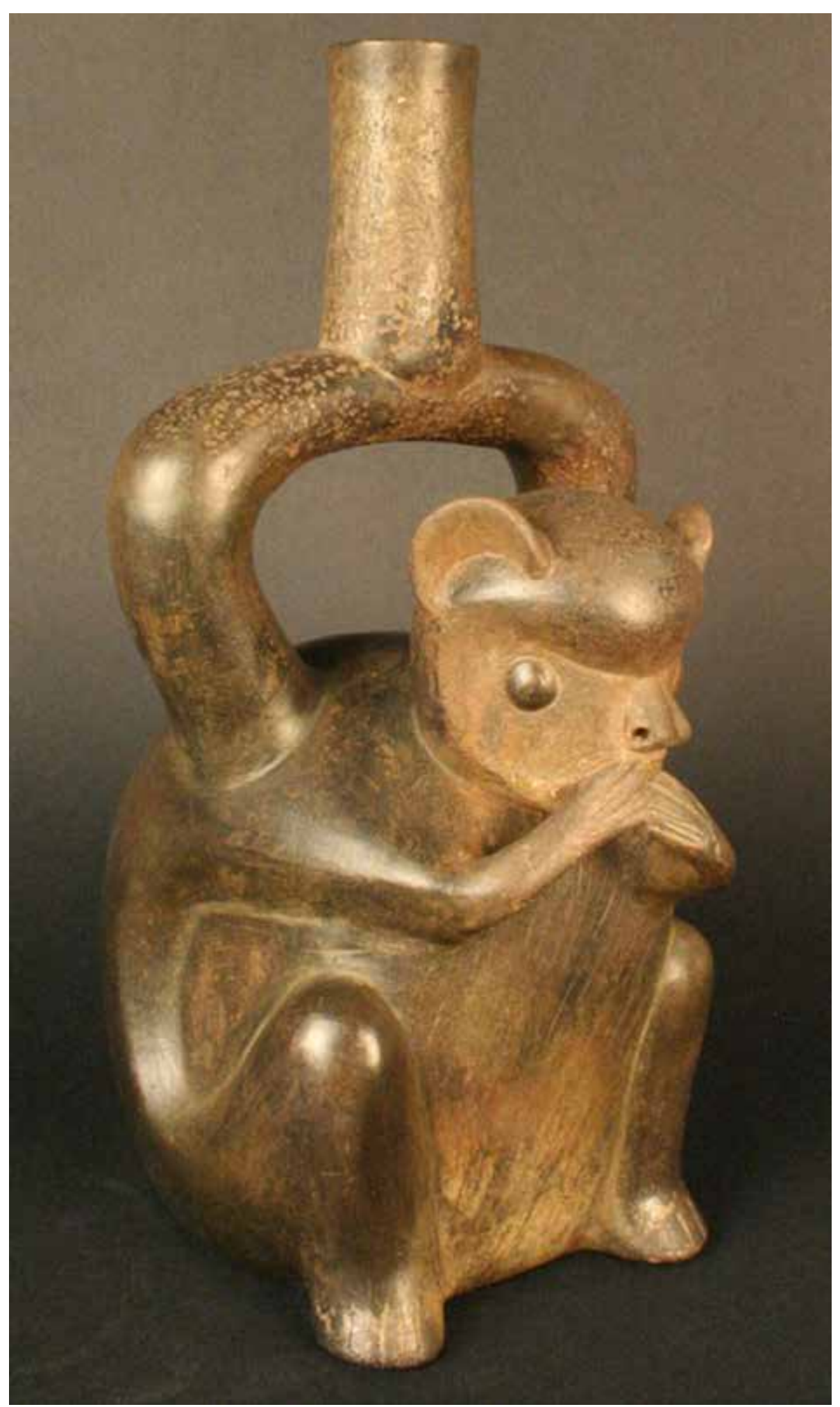

Figura 8. Vaso ritual con mono. Cerámica. Estilo Tembladera. Cultura Chavín. c. 700-400 a.C.

Fuente: Museo Chileno de Arte Precolombino) http://www.precolombino.cl/en/exposiciones/exposicion-permanente-america-precolombina-en-el-arte/andes-centrales/vitrina-chavin-y-sus-influencias/\#!prettyPhoto (15 noviembre 2014). 
montañas del oriente que proporcionaban la mayor fuente al respecto y de la que dependían los ríos para la irrigación de los campos, parece comprensible la asociación de esta figura con la fertilidad (Reinhard 1993). En la textilería de la misma cultura aparece ocasionalmente el mono, y en tal sentido Proulx lo destaca como a un personaje mítico, especialmente en la fase tardía (c. 500- 700 d.C) y lo relaciona a los contactos con la cultura moche. Muchas veces estos monos aparecen asociados a las cabezas trofeo e incluso los mismos monos pueden aparecer decapitados (Proulx 2007), lo que reforzaría sus vínculos con la fertilidad, ya que las cabezas trofeo funcionaron en Andes como la mejor forma de aludir a la conexión vida-muerte, necesaria para la abundancia y fertilidad (Frame 2001 y Arnold 2007). Finalmente, también en cerámicas Moche (costa Norte, c.0-700 d.C.) se ve al mono recolectando ulluchu, que es una planta que se utilizaba en los rituales que se hacían en la huaca de la Luna (c. 450-650 d.C) y que tenía efecto anticoagulante para beber la sangre de los prisioneros mutilados (Wassén 1989 y Rainer y Douglas 2015).

Destaca la vinculación que hacen Núñez y Castro entre la figura del mono y la idea de fertilidad, a partir del análisis iconográfico de un plato para ofrendas agrarias que presenta dos figuras de simios, hallado en la región del río Loa en Chile. Cruzando documentación correspondiente al proceso de extirpación, los autores recuerdan que los monos eran considerados un bien de privilegio, ya que se trasladaban vivos desde las yungas, por lo que fueron introduciéndose en el imaginario ritual en torno a mitos donde se pedía fertilidad. Esto se refuerza con la presencia de simios en la iconografía del Período Intermedio Tardío de la Cultura Arica (c. 900-1470 d.C.), donde es frecuente en diseños cerámicos, en asas y textiles e incluso en contextos funerarios. Los autores evalúan la etimología desde la lengua aymara, que refiere a simio como cusillu, equivalente a agüero bueno y que se ratifica con cussi como dicha o ventura. Luego refieren a una araña llamada Cussi Cussi, reconocida en el altiplano como buen agüero y es notable que en los geoglifos de Nazca aparezcan ambas figuras, reforzando la relación entre los simios y la fertilidad, asociada además a los requerimientos de agua en ámbitos desérticos (Nuñez y Castro 2011). Finalmente Dimitri Karadimas propone una interpretación de escenas prehispánicas a partir de una mitología vigente en el noroeste amazónico, buscando una trama común con Andes prehispánicos basada en una combinación de monos y formas estelares. En Carchi Pasto (Dpto. Nariño-sur de Colombia) las culturas de Capuli (c. 850-1250 d.C.) y Tuza (c. 1250-1500 d. C.) usan figuras de monos en número de cuatro, asociados a estrellas y al antagonismo entre los seres celestes, identificados con Orión. En la orfebrería de la zona los animales están ligados a racimos y frutas de palmas que remiten a las tierras bajas. También suelen aparecer cuatro monos en asas de vasijas Moche, como variantes
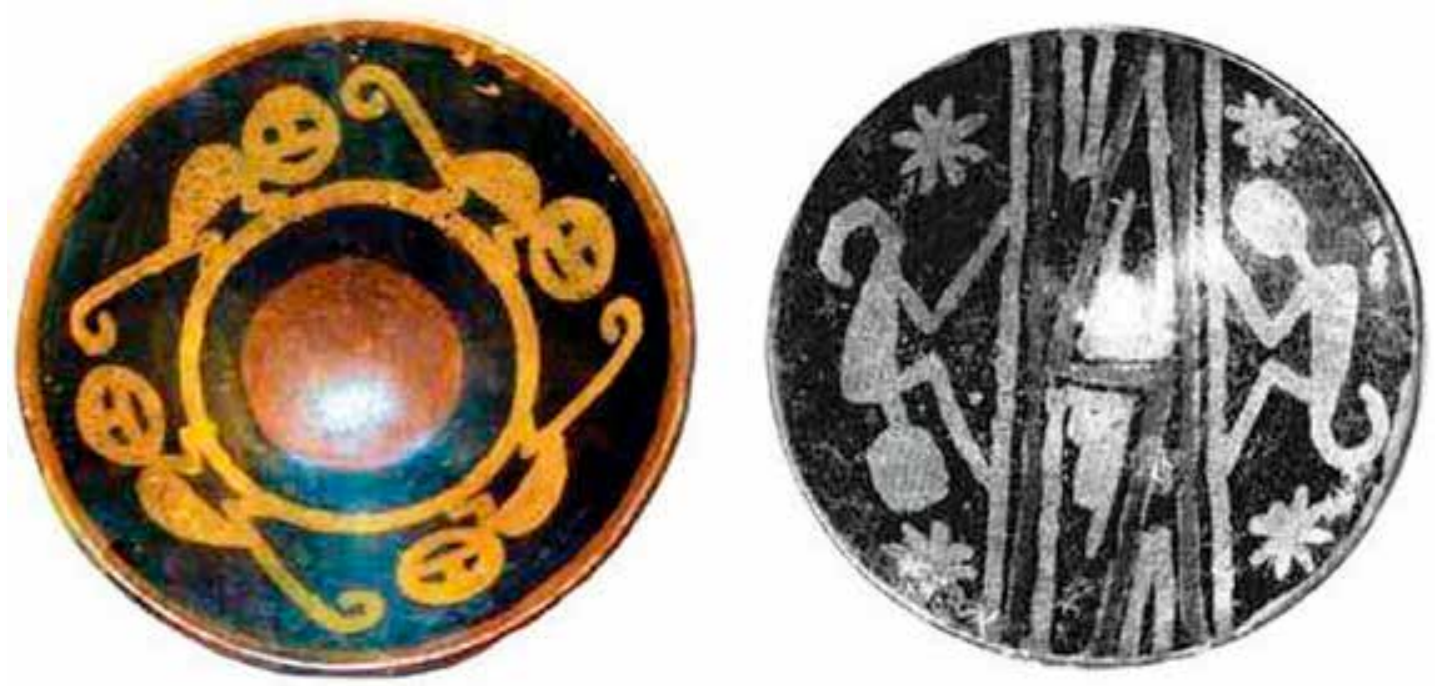

Figura 9. Variación combinatoria entre cuatro monos y estrellas en la iconografía Carchi-Nariño. Fuente: Karadimas 2014: 206. 
de elementos bélicos en escenas de embarcaciones nocturnas, representando a Orión, acompañante de los muertos (Karadimas 2014). Desde el punto de vista formal, en todos los casos las figuras de los animales son bidimensionales y aparecen esquematizadas, pero siempre se evidencia la referencia al modelo real. Figura 9.

En definitiva, prevalecen en América las asociaciones del mono con la abundancia y la fertilidad, por ser un bien de la tierra caliente, o en todo caso un animal exótico que fue valorado por su exclusividad. Asimismo, su vinculación con los astros se inscribe en las mismas concepciones cíclicas que refieren al orden del cosmos en armonía con las fuerzas de la naturaleza. Por otra parte, los autores que estudian el contexto colonial, dan por establecida la veracidad de la versión de Ávila referida en Gisbert, sosteniendo asimismo el carácter de deidad prehispánica y asumiendo una visión positiva del animal, pero sin explayarse demasiado en las significaciones americanas y olvidando referir a las connotaciones negativas de la iconografía cristiana.

\section{Algunas consideraciones}

En este punto es necesario establecer algunas consideraciones en relación con el contexto de ejecución de dichos motivos, esto es, en el marco del programa evangelizador.

Una de las cuestiones centrales que se presentó desde el comienzo del adoctrinamiento fue la dificultad de trasladar conceptos culturales y religiosos tanto desde una perspectiva lingüística como conceptual. Los inconvenientes en la transmisión de la doctrina tuvieron su impacto también en las formas artísticas, siendo que las políticas flexibles que buscaban facilitar la transmisión y comprensión del cristianismo por medio de la incorporación de elementos de la religiosidad andina, terminaban siendo frustradas. Así por ejemplo, la asimilación de la Virgen, Jesús y Santos con cerros y huacas, hacía volver a los nativos a sus antiguas prácticas religiosas, siendo esto más perceptible en la pintura y escultura:

Como también se averiguó en Huarochirí por el doctor Francisco de Ávila, que para adorar un ídolo en figura de mujer, llamado Chupixamor, y Mamáyoc, hacían fiesta a una imagen de nuestra Señora de la Asunción y para adorar un ídolo varón llamado Huayhuay hacían fiesta a un Ecce homo (Arriaga 1922 [1621]: 77).

Sin embargo en el caso de la ornamentación, el carácter en apariencia decorativa de las imágenes facilitaba el reemplazo por animales y plantas de la zona, evocando el vínculo de la religiosidad andina con el entorno natural, sin aparentar diferencias sustanciales.

Como se lee en las fuentes doctrinales más destacadas de la época, especialmente la producción jesuita desde los inicios de la evangelización, siguiendo las recomendaciones del general Francisco de Borja al padre Ruiz de Portillo (1567), el modelo de instrucción se apoyó en los apóstoles que debieron ya desde los primeros tiempos del cristianismo acomodar las reglas de la fe y mostrar tolerancia hacia las costumbres de los gentiles, si se deseaba tener éxito. Del mismo modo el jesuita José de Acosta recomendaba en su De Procuranda Indorum Salute, publicado en 1589, considerar las características culturales de los conversos antes de emprender la instrucción religiosa (Maranguello 2015). Además, las continuas reflexiones acerca de las posibilidades de la imagen para la tarea evangelizadora y el conocido sentido visual de los Ejercicios Espirituales de san Ignacio, alimentaron las teorías acerca de los beneficios de una comunicación no lingüística, que la orden propiciaba con entusiasmo (González 2014). Con esta concepción, y la preocupación de los doctrineros por la evangelización deficiente, cierta flexibilidad en relación con la búsqueda de lugares comunes entre ambas religiones, determinó la supervivencia de motivos de raigambre prehispánica adaptados al nuevo contexto ${ }^{8}$.

La importancia de la imagen para la instrucción religiosa fue un tema central del Concilio de Trento (1545-1563), que tuvo su impacto fundamentalmente en el III Concilio Limense (1582-83), y que estableció pautas que estuvieron vigentes durante todo el siglo XVIII. El peligro del culto hacia los ídolos mediante la utilización de imágenes respondía según lo establecido en el concilio romano a una forma desordenada de veneración que nada tenía que ver con la utilización que alentaba la iglesia. No obstante, para sortear este obstáculo se acudió a la ayuda de la palabra mediante el sermón, que cargaba con un sentido visual, ya que se acudía constantemente a las analogías con objetos del mundo reconocible 
por los conversos, y donde los elementos naturales tuvieron un papel destacado (Maranguello 2015). El jesuita Pablo José de Arriaga, uno de los principales extirpadores de idolatrías, recordaba a sus pares la importancia de este tipo de técnicas para que los conversos asuman afectivamente el dogma:

[...] Los sermones han de ser proporcionados a su capacidad (...) convenciéndoles con más razones naturales, que ellos entiendan, [...] Como yo vi, que lo hacía excelentemente uno de los Visitadores [...] sacaba en el catecismo una mazorca de maíz, y preguntándole de cuántos granos había nacido aquella mazorca, y respondiendo que de uno. ¿Pues cómo siendo este blanco, o negro, o colorado, (...) salen en esta mazorca unos granos blancos, otros negros, otros pardos? [...] A este modo han de ser los sermones (Arriaga 1922 [1621]: 117).

Paradójicamente, el jesuita evocaba un caso en donde, para referir al origen de los hombres, se utilizaba el maíz, elemento fundamental en la religiosidad andina. Este tipo de incongruencias constituyeron el marco de la evangelización en todo el virreinato y, lógicamente, también en la provincia de Chucuito.

Empero, es posible preguntarse aún por la autoría de las imágenes. Como demuestra la documentación del Archivo de Prelatura de Juli, sitio donde se encontraba la doctrina principal de los jesuitas, la ejecución de los programas artísticos de la última etapa de dominación hispánica (fines del siglo XVII y principios del siglo XVIII) estuvo a cargo de los grupos nativos. Ramón Gutiérrez (1978) fue uno de los primeros que avanzó en el estudio documental relativo a la construcción de las iglesias reduccionales de la zona circumtiticaca y tras el relevamiento de los libros de fábrica, ha dado cuenta de la importancia que adquirieron con el tiempo los artífices indígenas en la construcción de los templos de toda la provincia de Chucuito. $\mathrm{Si}$ en los conjuntos de la primera etapa, desarrollados a lo largo del siglo XVI y hasta mediados del siglo XVII, la participación local se limitaba casi exclusivamente a la obtención de materiales y a la mano de obra, con el tiempo y coincidiendo con el desarrollo de la ornamentación de las iglesias de la segunda etapa, desde mediados del siglo XVII hasta mediados del siglo XVIII, se ha demostrado que los nativos tuvieron una participación sustancial en la elaboración directa y la dirección de los programas ornamentales (Gutiérrez 1978). El autor analizó detenidamente el proceso, indicando que para fines del siglo XVI el 10 por ciento de indios tributarios en Chucuito estaban abocados a la mano de obra de los templos, aunque para esta época no encuentra documentación que avale otro rol por parte del indígena que el de una exclusiva mano de obra. Hacia principios del siglo XVII, la tendencia al reemplazo de los antiguos maestros españoles por indígenas y en menor grado mestizos, que apareció tímida con la participación del maestro indígena Bartolomé Zapana Huaylicolla para la iglesia de San Jerónimo de Asillo (c. 1590), quedaba notoriamente marcada hacia fines del siglo XVII y principios del siglo XVIII con la creciente presencia del artesanado indígena que según el autor modificaría las características arquitectónicas de la región, generando el fenómeno de la denominada arquitectura mestiza ${ }^{9}$ (Gutiérrez 1978). Para Gutiérrez, una de las características más importantes radicaba en el espíritu corporativo a nivel grupal, donde se formaban grupos de indígenas canteros, como es el caso de Santiago de Pupuja, entre los que se encontraban familias indígenas que transmitían los conocimientos artesanales en las mismas comunidades. Finalmente, el arquitecto destaca la transferencia paulatina hacia las generaciones subsiguientes de los roles del diseño y dirección, donde el indígena aplicó la tradición empírica de los maestros nativos que lo precedieron. Otros autores utilizaron posteriormente la misma documentación, entre ellos Antonio San Cristóbal (2000), Alexander Gauvin Bailey (2010) y Ricardo González (2010), quienes coinciden en gran parte con las hipótesis de Gutiérrez, asumiendo una participación cada vez más activa de los artífices indígenas durante el siglo XVIII, especialmente en el área del Collao y otras zonas alejadas de Lima y Cuzco, que eran los principales centros.

En este sentido y teniendo en cuenta que la ornamentación, por su apariencia meramente decorativa, era inaccesible en gran medida al control institucional, los elementos aportados por la cultura hispánica, como los grutescos de tradición grecolatina o los elementos iconográficos relativos a relatos cristianos, podían ser traducidos al lenguaje interno mediante reemplazos o equivalentes con elementos de la religiosidad andina y así devenir en una realidad perceptible 
para los conversos. Además del extendido uso de los elementos naturales para fines religiosos y medicinales, en el hostil ambiente del altiplano, tanto la producción agraria como los beneficios del clima debieron garantizarse para asegurar la existencia misma de la comunidad, por lo que la percepción del medio ambiente se expresaba como una relación que ligaba el orden social con el orden cósmico. Las teorías animistas ponen en primer plano una preocupación empática por los lugares y las características naturales, a los que se dota de identidades sociales y nuevos significados, y por lo tanto de un poder para actuar en el mundo humano, variando el grado o la intensidad de participación de las fuerzas de la naturaleza de acuerdo con el modo en que cada sociedad las involucra (Sillar 2009 y Allen 2015). En el caso del animismo andino, los lugares y elementos naturales tienen incluso mayor capacidad que el ser humano de actuar en la vida social, a lo que el hombre contrarresta con sus acciones, estableciendo comunicación y relación fluida para lograr beneficios (Sillar 2009).

Es por ello que resulta fundamental considerar los lazos entre los actores y los procesos involucrados. La exploración del universo del agente permite ampliar la concepción en torno a los artefactos, los que revelan la agencia del productor, en términos de Alfred Gell (1998). Al interior de esta compleja red, las imágenes de las portadas pretendían funcionar como medio de adoctrinamiento para los mismos productores (los artífices) y el resto de la comunidad. La iconografía, predominantemente fito y zoomorfa, evocaba al mundo natural tan profusamente representado en las producciones artísticas prehispánicas, y en este marco, resultaba significativa debido a la elevada religiosidad del hombre andino y el contacto permanente con la naturaleza. Esta situación no estuvo exenta de ambigüedades, ya que para la instrucción religiosa la utilización de analogías y discrepancias con la religión local mediante los elementos de la naturaleza, como se leía en el discurso de Arriaga, fue una estrategia habitual que permitía además ampliar las concepciones del paraíso cristiano (León Pinelo 1943 [1656]). Por otra parte, el hecho de que los españoles se hayan interiorizado con objetos y huacas que fueron el blanco de destrucción durante las campañas de extirpación, aumentó el poder de las fuerzas de la naturaleza, especialmente los cerros, pero también ríos, valles, plantas y animales, que eran indestructibles y que tenían el mismo grado de sacralidad y características vitales que las huacas devastadas (Sillar 2009).

Sin embargo, aun con el descubrimiento de la idolatría, se continuaron admitiendo tradiciones de la religiosidad andina, que junto con los elementos cristianos determinaron un procedimiento doctrinal que caía en contradicciones a medida que pasaban las décadas (Maranguello 2015). Sobran los ejemplos al respecto, y en este caso hemos mencionado el hecho de que a pesar de referirse Ávila al mono como ídolo prehispánico, habiéndolo destruido de las ventanas de una iglesia, menos de un siglo después lo veamos aparecer como motivo destacado en las portadas e incluso en las mismas ventanas, como en el caso de la iglesia de San Juan de Juli. Es importante destacar entonces no solo la organización y confección de las imágenes en manos de artífices indígenas y mestizos, sino además la iconografía que evoca el sacro mundo natural.

\section{Conclusiones}

En un contexto en el que los conversos debían pensar la religiosidad en nuevos términos, los elementos aportados por la cultura hispana que presentan iconografía relativa a los relatos cristianos devendrían en una realidad perceptible en la medida que fueron traducibles al lenguaje interno y aparecieron como elementos significativos para la cultura andina. Junto con otros elementos naturales, la figura del mono es elocuente, porque su presencia en las portadas aparece ambigua a simple vista. Su ubicación intersticial nos obliga a considerar las concepciones religiosas de ambos universos, pero al calor del nuevo contexto. El marco vegetal tropical nos remite a su antiguo sentido positivo y sus vínculos con la fertilidad, pero durante la evangelización podría ser parte de la invitación al nuevo paraíso, que ya no es el Antisuyu, sino el paraíso cristiano.

No obstante, si bien la ubicación de estos animales en las portadas de acceso a los diferentes espacios de culto no nos proporciona un elemento suficiente para inclinarnos por la opción de la iconografía americana, ya que aún con connotaciones negativas, en la tradición cristiana el mono se ubicaba en espacios reducidos de los capiteles y otros recodos en las iglesias, ponemos de relieve el lugar tan destacado que presenta cuando aparece en alguna portada de la 
zona y como parte de la abundancia de la selva, en contraposición al encadenamiento o situación de humillación y castigo en que aparecía en las iglesias románicas. Las figuras ostentan una jerarquía importante junto con el resto de los personajes de la iconografía cristiana, recibiendo al fiel en el ingreso al templo, fusionándose con flores y frutos que en muchos casos aparecían en las culturas andinas vinculadas a los rituales de fertilidad, en concordancia con el antiguo sentido americano de la figura del animal.

\section{Agradecimientos}

A mis colegas del proyecto UBACYT código 20020130100870BA.

\section{Referencias Citadas}

Acosta, J.

1954 [1590] Historia Natural y Moral de las Indias. Atlas, Madrid.

Arriaga P. J.

1922 [1621] La extirpación de la idolatría en el Perú. Dirigido al Rey N. S. en su Real Consejo. Imp. San Martín y Cia., Lima.

Allen, C.

2015 The whole world is whatching. New perspectives onandean animism. En The Arqueology of Wak'as. Explorations of the Sacred in the Precolumbian Andes. Editado por Bray Tamara, pp. 23-46. University Press of Colorado, Boulder.

Arnold, D. Y.

2007 Ensayo sobre los orígenes del textil andino: cómo la gente se ha convertido en tela. En Hilos Sueltos: Los Andes Desde el Textil, compilado por Denise Y. Arnold, Juan de Dios Yapita y Elvira Espejo, pp. 49-84. ILCA y Editorial Plural, La Paz.

Burger, R.

1993 El centro sagrado de Chavín de Huantar. En La Antigua América. El arte de los parajes sagrados, editado por Richard F. Townsend, pp. 265-277. The Art Institute of Chicago/ Grupo Azabache, México.

Charboneux Lassey, L.

1997 El Bestiario de Cristo. El Simbolismo Animal en la Antigüedad y la Edad Media (traducido por F. Gutiérrez). Ed. José Olañeta, Palma de Mallorca.

Cieza de León, P.

2005 [1550] Crónica del Perú. El señorío de los Incas. Fundación Biblioteca Ayacucho, Caracas.

Cobo, B. 1892 [1653]. Historia del Nuevo Mundo. II. Bustos Tavera I, Sevilla.

Frame, M.

2001 Blood, fertility, and transformation: Interwoven themes in the Paracas Necropolis Embroideries. En Ritual Sacrifice in Ancient Peru, editado por Elizabeth P. Benson y Anita G. Cook, pp. 55-92. Austin University of Texas Press, Austin.

García Arranz, J.

2013 El mono frugívoro y la Epifanía: en torno a la iconografía del tríptico de la Adoración de los Reyes Magos, atribuido a Adrián Isenbrandt, en el Museo del monasterio de Nuestra Señora de Guadalupe (Cáceres). En Alma Ars, Estudios de Arte e Historia en Homenaje al Dr. Salvador Andrés Ordax, pp. 211-219. Ediciones Universidad de Valladolid, Valladolid.
Gauvin Bailey, A.

2010 The reduction of Juli and the origins of collavino andean hybrid baroque (seventeenth and eighteenth centuries). En The Andean Hybrid Baroque: Convergent Cultures in the Churches of Colonial Perú, pp. 163-198. University of Notre Dame Press, Paris.

Gell, A.

1998 The problem defined: the need for anthropology of art y The theory of the art nexus. En Art and Agency: an Anthropological Theory, pp. 1-28. Clarendon Press, Oxford.

Gisber, T. y Mesa, J.

1985 Arquitectura Andina. Historia y Análisis. Arsanz y Vela, La Paz.

Gisbert, T.

1981 Iconografía y Mitos Indígenas en el Arte. Gisbert y Cía., La Paz.

1999 El Paraíso de los Pájaros Parlantes. La Imagen del otro en la Cultura Andina. Plural, La Paz.

González, R.

2010 Chucuito, fragmentos de una historia. Catálogo de exposición de la muestra en el Centro Cultural Paco Urondo. Compilado por Ricardo González. FFyL- UBA, Bs. As.

2014 "La compañía de Jesús y la renovación de la iconografía ornamental en el Sur Andino". Actas VII Encuentro Internacional sobre Barroco, PROINSA, La Paz: 271-283.

Guglielmi, N.

1971 El Fisiólogo, Bestiario Medieval. Editorial Universitaria, Buenos Aires.

Gutiérrez, R.

1978 Arquitectura del Altiplano Peruano. Libros de Hispanoamérica, Buenos Aires.

Karadimas, D.

2014 Las alas del tigre: acercamiento iconográfico a una mitología común entre los Andes prehispánicos y la amazonía contemporánea. Amazonía. Memorias de la Conferencias Magistrales del 3er Encuentro Internacional de Arqueología Amazónica, pp. 203-33. Ministerio Coordinador de Conocimiento y Talento Humano-IKIAM, Quito.

Maranguello, C.

2011 ¿Un sentido alterno en la iconografía de los templos coloniales de Chucuito? A propósito del bautisterio de Santa Cruz de Juli. VIII Jornadas Nacionales de Investigación en Arte en Argentina, Instituto de Arte Americano UNLP, La Plata.

2015 Religiosidad andina y fuentes doctrinales. Consideraciones sobre el contexto evangelizador de desarrollo de la iconografía 
ornamental en Chucuito colonial. Temas Americanistas 35: 37-59, Universidad de Sevilla.

Mulvany de Peñaloza, E.

1984 Motivos fitomorfos de alucinógenos en Chavín. Chungara 12: 57-80, Universidad de Tarapacá, Chile.

Núñez, L. y Castro, V.

2011 iCaiatunar, caiatunar! Pervivencia de ritos de fertilidad prehispánica en la clandestinidad del Loa (norte de Chile). Estudios Atacameños 42: 153-172.

Okada, $\mathrm{H}$.

2006 Inverted exoticism? Monkeys, parrots, and mermaids in Andean Colonial Art. En The Virgin, Saints, and Angels: Latin American Paintings, editado por Suzanne StrattonPruitt, pp. 67-79. Stanford University, Stanford.

Poma de Ayala, G.

1936 [1614] Nueva corónica y Buen gobierno. Institut d'Ethnologie, Université de Paris.

Pinelo, L.

1943 [1656] El Paraíso en el Nuevo Mundo. II. Torres Aguirre, Lima.

Polia Meconi, M.

1999 La Cosmovisión Religiosa Andina en los Documentos Inéditos del Archivo Romano de la Compañía de Jesús (15811752). Pontificia Universidad Católica del Perú, Lima.

Proulx, D.

2007 Nasca Ceramic Iconography (17 mayo). http://people. umass.edu/proulx/online_pubs/Nasca_Ceramic_Iconography_ Overview.pdf (15 noviembre 2014).

Rainer B. y Douglas S.

2015 Plantas medicinales de los Andes y la Amazonía. La flora mágica y medicinal del Norte de Perú. Centro
William Brown, Jardín Botánico de Missouri. Graficart, Trujillo.

Reinhard, J.

1992 La interpretación de las líneas de Nazca. En La Antigua América. El arte de los Parajes Sagrados, editado por Richard F. Townsend, pp. 291-301. The Art Institute of Chicago/ Grupo Azabache, México.

Rick, J.

2012 La evolución de la autoridad y poder en Chavín de Huantar. Chavín de Huantar: Protocolo de las Intervenciones Arqueológicas, compilado por Luis Enrique Barba, Jesica Seminario Mesía y Ana María Flores B., pp. 63-76. Instituto Andino de Estudios Arqueológico-Sociales, Perú.

San Cristóbal, A.

2000 La controversia de los aportes europeos en la arquitectura virreinal peruana. En Anales 8, Museo de América, pp. 9-28. Secretaría general técnica, Madrid.

Sillar, B.

2009 The Social Agency of Things? Animism and Materiality in the Andes. Cambridge Archaeological Journal 19: 36979. McDonald Institute for Archaeological Research.

Walker Vadillo, M.

2013 Los simios. Revista Digital de Iconografía Medieval vol. 9: 63-77.

Wassén $\mathrm{H}$.

1989 'El 'Ulluchu' en la iconografía y ceremonias de sangre moche: la búsqueda de su identificación”, Boletín del museo chileno de arte precolombino, $\mathrm{N}^{\mathrm{o}} 3$ : 25-45.

Woldemar, J.

1952 Apes and ape lore in the middle ages and the renaissance. Warburg Institute, Londres.

\section{Notas}

1 "Los monos son unas bestias feísimas similares a nosotros". La traducción aparece en varios textos, entre ellos en Walker Vadillo (2013: 69).

2 Véase, entre otros, Darcheville, Patrick, 2011, Bestiaire de l'art sacré. Paris: E-Edité, pp. 64 y 65; Suchaux Gaston y Pastoureau Michel, 2002. Le Bestiarire Medieval. Dictionnaire historique et bibliographique. Paris: Le Léopard d'or, pp. 133 y 134.

3 Para profundizar en este aspecto, véase el exhaustivo trabajo de Woldemar, J. 1952. Apes and ape lore in the middle ages and the renaissance. Warburg Institute. Londres. El autor es evocado en los artículos más actuales que refieren al tema.

$4 \quad$ La importancia del mundo vegetal para la medicina y las prácticas rituales (muchas veces unidas), es un tema que ha sido ampliamente abordado y que hemos considerado en los artículos de nuestra autoría citados. Por otra parte, hemos abordado el estudio interdisciplinario de la iconografía en cuestión, con la colaboración de profesionales del área etnobotánica del Instituto de botánica Darwinion y Instituto Nacional de Antropología y Pensamiento Latinoamericano, Dr. Fernanda Rodríguez (CONICET).

5 La iglesia de San Juan de Juli fue comenzada antes de 1590, según un contrato de ese año, pero corresponde al tipo de iglesias dieciochescas, ya que fue reconstruida durante esta época, junto con la ornamentación arquitectónica de portadas y ventanas (González 2010).

6 A su vez, aparece un mono junto con otros personajes, entre ellos la sirena, en los laterales del retablo de la iglesia de Corque en Oruro, siglo XVIII (Gisbert y Mesa 1985; Okada 2006).

7 En el caso de los animales de la fachada lateral de la iglesia de San Juan de Juli, sostenemos, al igual que la mayor parte de los estudiosos, que no se trata de monos sino de felinos.

8 Hemos estudiado previamente el contexto de producción de las fuentes doctrinales en la provincia de Chucuito, destacando la tarea del padre José de Acosta, quien plasmó el espíritu de la orden de la Compañía de Jesús en $D e$ Procuranda Indorum Salute (publicado en 1589) y que fue considerado el tratado de evangelización por excelencia. Por otra parte, Acosta tuvo una participación sustancial en el Tercer Concilio Limense (1582-83), el que marcó una redirección en la metodología doctrinal, hasta la expulsión de la orden de América en 1767 (Maranguello 2015).

9 El término "mestizo" acuñado por Ángel Guido en 1937 en relación con el arte y arquitectura colonial, continúa siendo eje de discusión y revisión a la luz de nuevas teorías de dimensión etnohistórica en los estudios de historia del arte. 